\title{
Aquatic Macrophytes Determine the Spatial Distribution of Invertebrates in a Shallow Reservoir
}

\author{
Se-Hwan Son ${ }^{1}$, Soon-Jik Kwon ${ }^{2}$, Ji-Hyeok Im $^{1}$, Seong-Ki Kim ${ }^{3}$, Dongsoo Kong ${ }^{1, *}$ and Jong-Yun Choi ${ }^{3, *(D)}$ \\ 1 Department of Bioconvergence, Kyonggi University, Suwon 16227, Korea; son-s.h@hanmail.net (S.-H.S.); \\ frogih99@daum.net (J.-H.I.) \\ 2 Institute for Ecological Resource, Seoul 02783, Korea; triopsidae@naver.com \\ 3 National Institute of Ecology, Seo-Cheon Gun 33657, Korea; skkim@nie.re.kr \\ * Correspondence: dskong@kgu.ac.kr (D.K.); jyc311@naver.com (J.-Y.C.); Tel.: +82-31-249-9649 (D.K.); \\ +82-41-950-5473 (J.-Y.C.)
}

check for updates

Citation: Son, S.-H.; Kwon, S.-J.; Im, J.-H.; Kim, S.-K.; Kong, D.; Choi, J.-Y. Aquatic Macrophytes Determine the Spatial Distribution of Invertebrates in a Shallow Reservoir. Water 2021, 13, 1455. https://doi.org/10.3390/ w13111455

Academic Editor: Peter Goethals

Received: 16 April 2021

Accepted: 19 May 2021

Published: 22 May 2021

Publisher's Note: MDPI stays neutral with regard to jurisdictional claims in published maps and institutional affiliations.

Copyright: (c) 2021 by the authors. Licensee MDPI, Basel, Switzerland. This article is an open access article distributed under the terms and conditions of the Creative Commons Attribution (CC BY) license (https:// creativecommons.org/licenses/by/ $4.0 /)$.

\begin{abstract}
Aquatic macrophytes determine the physical structure of many microhabitats in water and strongly influence the distribution of various aquatic animals. In this study, we analyzed the main microhabitat characteristics that affected the spatial distribution of invertebrates in shallow wetlands of South Korea (Jangcheok Reservoir). Environmental variables, macrophyte biomass, and invertebrate groups were used to analyze invertebrate distribution using a self-organizing map (SOM). Thirteen invertebrate groups were mapped onto the SOM, and each group was compared with the distribution of environmental variables and macrophyte biomass. Based on a U-matrix, five clusters were categorized according to Euclidean distance on the SOM. Invertebrate groups were closely related to macrophyte biomass. In particular, Lymnaeidae, Physidae, Viviparidae, Ecnomidae, and Hydrophilidae were abundant in quadrats with a high cover of Paspalum distichum and Nelumbo nucifera. Bithyniidae and Coenagrionidae were strongly associated with Trapa japonica and Hydrocharis dubia, whereas Planorbidae, Corduliidae, and Hydrophilidae were abundant with a high cover of Typha orientalis. Similar habitat preferences were found in a survey of gastropod distribution on the surface of each macrophyte species. The results clearly indicated that invertebrate distribution clusters were related to the spatial distribution of aquatic macrophytes in a shallow wetland.
\end{abstract}

Keywords: microhabitat; habitat heterogeneity; gastropods; self-organizing map; spatial pattern

\section{Introduction}

The physical structure and heterogeneity of microhabitats in freshwater ecosystems clearly affect the distribution patterns and species diversity of biological communities [1,2]. Biological interactions, such as competition and predation, are strongly mediated by the habitat structure of microhabitats and play a crucial role in determining local biodiversity [3]. For example, excessive foraging by predators leads to a rapid decrease in prey groups, which in turn leads to negative population growth in predators owing to food depletion [4]. In addition, accelerated competition induces the dominance of some species, which has a cascade effect on the community structures of other trophic levels (i.e., communities in prey-predator relationships) within the food web [5]. Empirical studies have suggested that in microhabitats with more structures of different forms and shapes, diverse species can more efficiently use, occupy, and colonize spaces, thus making it an efficient habitat [6]. The presence of efficient microhabitats not only helps the survival and stable population growth of prey populations but can also contribute to the continuous provision of food items for predators [7]. The efficiency of microhabitats is determined by the morphological characteristics (e.g., size or length) of animals or by their interactions with other species or communities. In general, complex or heterogeneous microhabitats can support higher abundance and diversity of animals because they form environmental mosaics where different structural characteristics coexist $[7,8]$. 
Aquatic macrophytes, which are frequently distributed in freshwater ecosystems, such as wetlands and shallow reservoirs, play a crucial role in the physical microhabitat structure $[9,10]$. Macrophytes differ in their occupied space or morphological characteristics depending on the species; thus, local microhabitat structures are dependent upon their species composition and distribution. Therefore, wetlands or shallow reservoirs covered by diverse plant species form complex and heterogeneous habitats [11,12]. Among the various life forms of aquatic macrophytes, the heterogeneous arrangements of the leaves and stems of submerged plants contribute greatly to microhabitat complexity [13]. Thus, areas with a high proportion of submerged plants are favored as habitats and refuges for various animals [14]. Van Donk and van de Bund [15] suggested that the presence of submerged plants, such as charophytes, strongly hindered the search for food by predators, such as fish, and contributed positively to the species diversity and density of zooplankton (e.g., rotifers and cladocerans). Furthermore, epiphytic cladoceran species, such as Chydorus spp. and Alona spp., are more abundant on the leaves and stems of submerged macrophytes than on other plants [16]. In contrast, emergent or free-floating macrophytes are less efficient as habitats because the submerged parts occupy a small space (e.g., water surfaces) and have a relatively simple structure in the water [17]. However, dependence on emergent or freefloating macrophytes may increase in areas where submerged macrophytes do not exist or are sparsely distributed [18]. Choi et al. [19] suggested that small-sized microinvertebrates, such as rotifers, can also be abundant in the narrow space around the roots of free-floating macrophytes such as Spirodela polyrhiza and Salvinia natans.

Studies evaluating the relationship between aquatic macrophytes and animals have focused primarily on fish, zooplankton, and microinvertebrates [20-22]. These studies have shown that aquatic macrophytes contribute to a decrease in the foraging activity of predators, thus supporting a high abundance and diversity of zooplankton and young fish. However, there is relatively little information on the interactions between invertebrates and macrophytes in freshwater ecosystems. In addition, the fact that most invertebrates (e.g., Ephemeroptera, Trichoptera, and Diptera) prefer lotic environments may be a reason for the lack of research on the relationships between aquatic macrophytes and invertebrates in lentic ecosystems $[23,24]$. Previous studies found that aquatic macrophytes clearly increase the density and diversity of invertebrates, such as odonatan larvae and gastropods [25-27], because aquatic macrophytes not only increase predator avoidance but also provide stable food sources [28]. In rivers and streams, littoral vegetation can decrease water velocity by up to 42 times and support invertebrate density up to nine times higher than that in open water [29]. The density and species diversity of invertebrates are also high in areas covered by aquatic macrophytes [30,31]. Moreover, the submerged leaves, stems, and roots of plants provide additional oxygen in their vicinity [32], making them efficient habitats for various invertebrates.

Freshwater gastropods are abundant in areas with a high cover of aquatic macrophytes as they move slowly consuming the algae attached to aquatic macrophytes [32]. Previous studies have suggested a strong association between aquatic macrophytes and gastropods [32-35]. Gastropods play an important role as the primary consumer of periphytic or epiphytic algae in the freshwater food web. These algae can be found primarily in areas with a high cover of aquatic macrophytes, in contrast to the pelagic pathways originating from phytoplankton [35]. However, despite the ecological importance of gastropods in freshwater ecosystems, comparatively few studies have focused on the interactions between aquatic macrophytes and gastropods. As a habitat for gastropods, the species composition and arrangement of aquatic macrophytes have rarely been considered.

In this study, we sought to elucidate the responses of invertebrates to changes in microhabitat structure caused by aquatic macrophytes, with the aim of advancing our current understanding of the spatial distribution of invertebrates in freshwater ecosystems. In addition, we suggest management strategies, such as enhancing habitat functions, to increase the species diversity of invertebrates based on our findings. The aims of this study were to identify (1) changes in invertebrate community structure and abundance in relation 
to aquatic macrophytes, and (2) the distribution patterns of gastropods attached to each macrophyte species. We predicted that the microhabitat structure related to macrophytes would influence invertebrate community composition and abundance. To test this hypothesis, we investigated the Jangcheok Reservoir in South Korea, which supports a diverse distribution of plant species. Understanding the effect of different microhabitat structures formed by aquatic macrophytes on gastropod distribution will provide additional information on the ecological functions of freshwater ecosystems.

\section{Materials and Methods}

\subsection{Study Area}

Jangcheok Reservoir is a riverine wetland located in the middle-lower reaches of the Nakdong River basin in southeast South Korea. There are many wetlands and reservoirs in this area because the soil drains poorly and the summer-concentrated rainfall leads to frequent flooding [36,37]. Many relatively large lentic freshwater ecosystems are distributed in this region, including the Upo Wetland, Junam Reservoir, Pyeonggi Wetland, and Jangcheok Reservoir [2]. The survey area is located in a temperate climate zone with four distinct seasons, which leads to high succession of biological communities. Water temperatures begin to rise in February, peak in August, and then gradually decrease toward December. The population growth of aquatic organisms is concentrated from spring to autumn (March-November). In winter (December-February), there are few active biological communities owing to the low water temperature $\left(<5{ }^{\circ} \mathrm{C}\right)[36,37]$. Jangcheok Reservoir has an area of $0.5 \mathrm{~km}^{2}$, and the main water sources are rainfall and groundwater. The reservoir is located near the Nakdong River, but it is not connected to the river by waterways or tributaries. In the dry season (December-May), the water depth ranges from $0.2 \mathrm{~m}$ and $1.2 \mathrm{~m}$ (shoreline and center, respectively); in the rainy season (summer and autumn), the depth increases to $0.8 \mathrm{~m}$ and $1.4 \mathrm{~m}$ at the shoreline and center, respectively [36]. The water surface is completely covered by various aquatic macrophytes from spring to autumn, and their spatial distribution differs from the shoreline to the center.

\subsection{Monitoring Strategy and Statistical Analysis}

We monitored the study area during spring (May-June) when weather conditions were relatively stable to avoid disturbance caused by summer rainfall [36,37]. We selected 50 sampling sites in the littoral zone (>0.6 m depth) at Jangcheok Reservoir (Figure 1) based on the different species composition of aquatic macrophytes. Areas with water depths $0.6 \mathrm{~m}$ had a low abundance of aquatic macrophytes. At each sampling site, quadrats $\left(1 \times 1 \mathrm{~m}^{2}\right)$ were established to investigate the environmental variables and invertebrate communities (three times per sampling site).

We measured the following environmental variables: water depth, $\mathrm{pH}$, conductivity, turbidity, and chlorophyll-a concentration. The water depth was measured using a steel ruler. The $\mathrm{pH}$ and conductivity were recorded using an Orion 250A pH meter (Orion Research Inc., Boston, MA, USA) and a conductivity meter (model 152; Fisher Scientific, Hampton, NH, USA), respectively. To measure turbidity and chlorophyll-a concentration, $2 \mathrm{~L}$ water samples were collected from each quadrat. Turbidity was measured using a turbidimeter (Model 100 B; HF Scientific Inc., Ft. Myers, FL, USA). The water samples were filtered through a mixed cellulose ester membrane filter (Advantech Model No. A045A047A; pore size: $0.45 \mathrm{~mm}$ ), and the filtrates were used to determine the concentration of chlorophyll-a based on Wetzel and Likens [38]. 

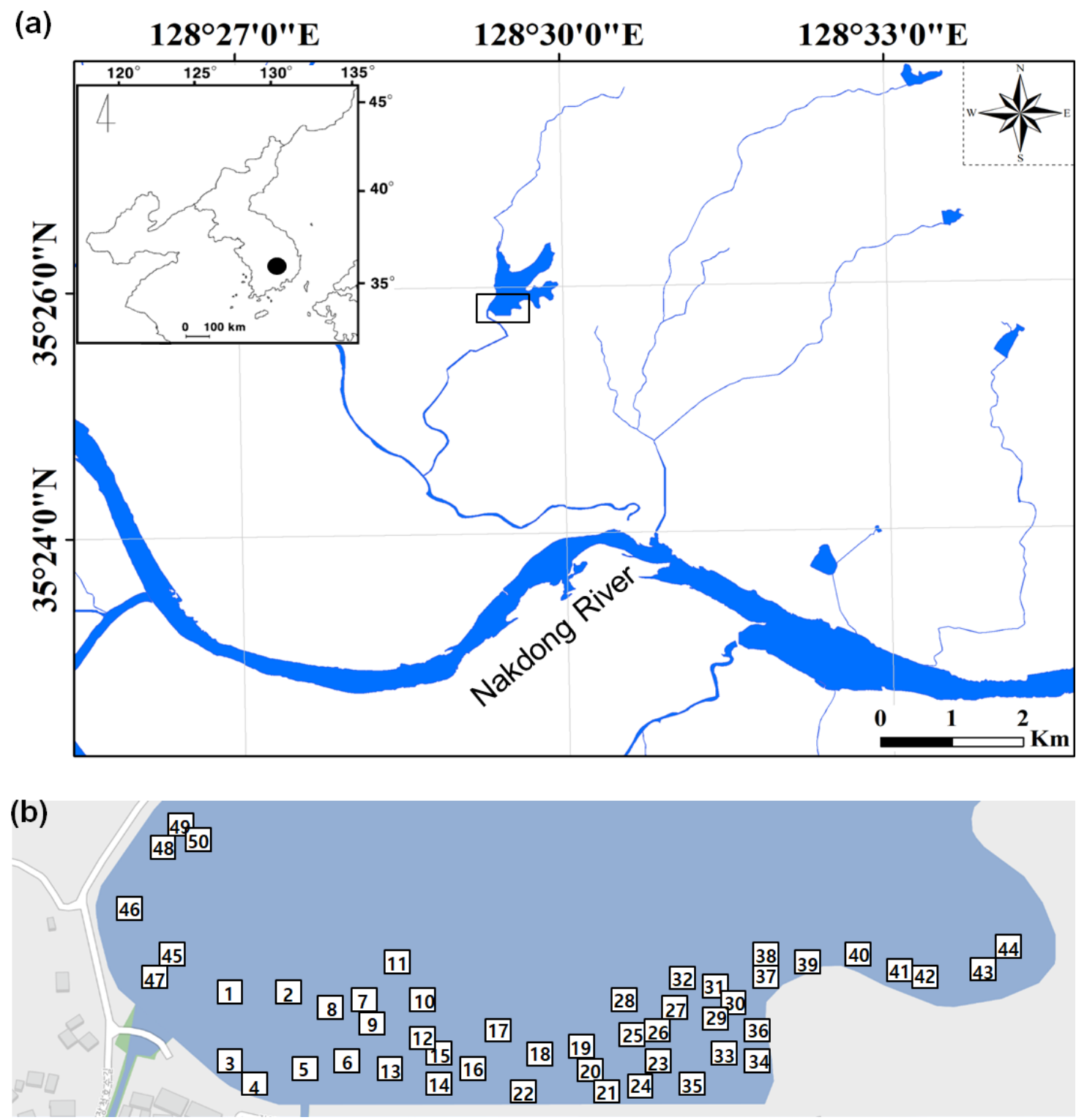

Figure 1. Map of the study area in mid-lower reaches of Nakdong River (a). The sampling sites are represented by rectangles $(\square)$. Upper-left inset indicates the Korean Peninsula and study area $(\bullet)$. Fifty quadrats were established based on the different species composition of aquatic macrophytes (b).

In each quadrat, invertebrates were collected for approximately 30 min using a stainless-steel sampler ( $40 \mathrm{~cm}$ width, $650 \mu \mathrm{m}$ mesh). Based on the habitat preference of invertebrate communities, we collected as many individuals as possible by sweeping over the bottom sediment layers and over the leaves and stems of aquatic macrophyte species. The sampling protocol was the same for all quadrats, and the 50 quadrats represented the main habitats within the littoral area. The collected invertebrates and organic material, including plant debris, were preserved in 10\% formaldehyde. In the laboratory, each sample was washed through a $900 \mu \mathrm{m}$ mesh sieve, and the leaves, stems, and other debris were removed. The resulting material was preserved in $80 \%$ ethanol solution. Individual invertebrates were separated and identified to species level according to Yoon [39], Kwon et al. [40], and Kawai and Tanida [41]. We established a species list of invertebrates for each quadrat and compared the density of gastropods (Cipangopaludina chinensis malleata, Hippeutis cantori, Parafossarulus manchouricus, Physa acuta, Polypylis hemisphaerula, and Radix auricularia) with that of other invertebrate species. After invertebrate collection, 
the aquatic macrophyte species in each quadrat were collected to estimate their biomass (dry weight).

To understand gastropod distribution in the microhabitats formed by aquatic macrophytes, we further investigated the density of gastropods attached to each macrophyte species in spring (May) and autumn (October). Two liters of reservoir water was filtered through $30 \mu \mathrm{m}$ mesh filter paper to remove microorganisms, and the water was stored in $3 \mathrm{~L}$ tanks. This water was used to temporarily store gastropods. We allocated one tank per macrophyte species in the quadrat, and the number of tanks for each square was determined by the number of sampled macrophyte species. Collected macrophytes were shaken vigorously 50-60 times to detach all gastropods, and individuals identified by the naked eye inside the tanks were also detached. Gastropods that sank in the water were filtered using a $150 \mu \mathrm{m}$ mesh net. The collected macrophyte samples were dried at $60{ }^{\circ} \mathrm{C}$ for $48 \mathrm{~h}$ and weighed using an electronic microbalance (Mettler, AE 240, Hamilton Bonaduz AG, Switzerland) to obtain their dry weight (g dry weight, gdw). Only the submerged parts of the macrophytes were considered as a substrate for gastropods because these animals inhabit underwater environments. Therefore, we removed the organs emerging above the water surface (i.e., stalks and flowers) from all macrophyte species. The density of gastropods attached to macrophytes (10 species: Paspalum distichum (L.), Typha orientalis Presl., Spirodela polyrhiza (L.) Sch, Salvinia natans (L.) All., Nelumbo nucifera Gaerth., Trapa japonica Flerow, Hydrocharis asiatica Miq., Ceratophyllum demersum L., Hydrilla verticillata (Lf), and Najas graminea Delile) was expressed as the number of individuals per gdw of each macrophyte species (ind. $\mathrm{g}^{-1} \mathrm{dw}$ ). In addition, we examined the differences in the density of gastropods and epiphytic algae among macrophyte species using one-way ANOVA test in SPSS version 20 (IBM Corp., Armonk, NY, USA).

To further improve our understanding of invertebrate distribution on macrophyte species, we additionally collected samples of epiphytic algae from the leaves and/or stem surface of each macrophyte species using a brush. Epiphytic algal samples were preserved with Lugol's solution (ca. 5\%), and algal cells (identified to class level; such as Chlorophyceae, Bacillariaceae, Cyanophyceae, Euglenophyceae, Chrysophyceae, Synurophyceae, and Dinophyceae) were counted under a Zeiss IM 35 inverted microscope at $\times 400$ magnification (Carl Zeiss Canada Ltd., Toronto, BC, Canada).

\subsection{Self-Organizing Map}

The self-organizing map (SOM) stems from the Kohonen network [42], which is an unsupervised learning algorithm. The SOM is widely used as a tool for mapping high-dimensional data into a two-dimensional representational space [43-45]. The SOM network is a competitive system in which the neurons (i.e., sample units) in a Euclidean map space compete with one another, converting non-linear relationships into simple geometric relationships. In the present study, the invertebrate groups and environmental data were used as input variables ( $\mathrm{x}_{\mathrm{i}} ; \mathrm{i}$ is the number of input variables) for SOM modeling. Invertebrates that accounted for $>5 \%$ of the total invertebrate abundance were included in the analysis. This was because the main goal of this study was to discover a general pattern of invertebrate distribution in wetland systems. Typically, analyzing ecological data suffers from problems such as non-linearity, multimodality, many zeros, or multicollinearity [46], which often hinders the discovery of the general pattern of ecosystem dynamics from a given dataset $[36,47]$. Therefore, we focused on the more abundant species in the wetland. Every node of the output layer, $\mathrm{j}$, was connected to every node in the input layer i. A hexagonal array of neurons was selected. The weight vector $w(t)$, representing the connection between the input and output layers, consisted of a weight value, $w^{i j}(t)$, and was adaptively changed at each iteration, $t$, as the training proceeded. In the initial stage of training, w(t) was randomly and uniformly distributed in the network architecture. As input signals entered the network, each neuron computed the summed distance between the weight and input. The neuron with the maximum response to the given input data was selected as the winning neuron, and its weight vector represented the minimum distance 
to the input vector. The winning neuron and its neighbors were determined by changing the weights to reduce the distance between the weight and input vector. Further details of this process were described by Park et al. [48].

There are no strict rules regarding the choice of the number of output neurons [49]; thus, we trained the SOM with different map sizes to select the most suitable model. During the training process, the number of nodes comprising the SOM plane was determined to be adjacent to $5 \times \mathrm{n}$ (where $\mathrm{n}$ indicates the number of samples; [50]). In this case, $\mathrm{n}$ was the number of sampling sites in this study area. From a variety of map structures with different sizes, we selected the optimal structure based on the minimal values for quantization (QE) and topographic errors (TEs) [51,52]. The lower the values obtained from both error parameters, the better the SOM model was configured; that is, the map model represented the input data pattern more closely. After selecting the optimal SOM structure, each input variable was projected onto the two-dimensional SOM plane with a grayscale gradient; the inputs were then clustered according to the U-matrix. The U-matrix calculates distances between neighboring map units (nodes), and these distances can be visualized to represent clusters using a grayscale display on the map [42]. A hierarchical cluster analysis was conducted according to the Ward linkage method using Euclidean distance to define the cluster boundaries in the SOM units.

To analyze the contribution of input variables to the cluster structures of the trained SOM, each input variable (component) calculated during the training process was visualized in each node on the trained SOM map in grayscale. Based on the component planes, correlation coefficients were calculated between the component pairs in both the observed and calculated data. When an appropriate SOM model was obtained from the training process, we identified the data samples collected by each cluster. We then calculated the averages of the input variables in accordance with clusters and investigated the environment and invertebrate distribution pattern.

The gradient range was determined using the mean invertebrate abundance. We used MATLAB 6.1 (MathWorks, Inc., Natick, MA, USA) and the SOM Toolbox (Helsinki University of Technology, Helsinki, Finland) to develop the SOM model. Readers are recommended to consult the following website (http:/ / www.cis.hut.fi/projects/somtoolbox/, accessed on 16 April 2021) to discover how to utilize the SOM Toolbox.

\section{Results}

\subsection{Environmental Variables and Invertebrate Distribution}

There was relatively little variation in the environmental variables among the sampling sites (Table 1). Although some sampling sites had considerably high or low values, the coefficients of variation (CV; standard deviation/mean $\times 100 \%$ ) were lower than $50 \%$. The biomass of each differed among sampling sites. A total of 10 species of aquatic macrophytes were found in the study area: P. distichum, T. orientalis, S. polyrhiza, S. natans, N. nucifera, T. japonica, Hydrocharis dubia, C. demersum, H. verticillata, and N. graminea.

A total of 41 invertebrate species were identified in the 50 quadrats. Radix auricularia was the most common in the study area (relative abundance: $22.5 \%$ ), followed by Hippeutis cantori (19.1\%), Physa acuta (16.7\%), and Parafossarulus manchouricus (9.4\%). The remaining invertebrate species accounted for $<7 \%$ of the total abundance. The abundance and species richness of invertebrate communities differed among the 50 quadrats (Figure 2; one-way ANOVA; $p<0.05)$. The highest number of invertebrate species was found in quadrat 27 (18 species), followed by quadrats 2 ( 16 species) and 21 ( 14 species). We found $<10$ species of invertebrates in 30 quadrats. However, the quadrats with high invertebrate species richness did not match the abundance of invertebrates. Quadrat 21 supported the highest abundance of invertebrates, followed by densities of 78 to 86 ind./ $\mathrm{m}^{2}$ at sites 9,13 , and 15 . 
Table 1. Mean physicochemical parameters and macrophytes measured at 50 sampling sites.

\begin{tabular}{|c|c|c|c|c|c|c|}
\hline Factors & Variables & Units & $\operatorname{Max}$ & Min & Mean \pm SD & CV $(\%)$ \\
\hline \multirow{5}{*}{$\begin{array}{l}\text { Environmental } \\
\text { variables }\end{array}$} & Water depth & $\mathrm{cm}$ & 60 & 17 & $46 \pm 26.2$ & 26.2 \\
\hline & $\mathrm{pH}$ & - & 7.4 & 7.1 & $7.2 \pm 0.0$ & 0.7 \\
\hline & Conductivity & $\mu \mathrm{cm}^{-1}$ & 235.1 & 205.6 & $217 \pm 6.2$ & 2.8 \\
\hline & Turbidity & NTU & 27.4 & 14.2 & $21.0 \pm 3.4$ & 16.1 \\
\hline & Chlorophyll-a & $\mu g \mathrm{~L}^{-1}$ & 26.1 & 6.2 & $12.9 \pm 3.8$ & 29.1 \\
\hline \multirow{10}{*}{ Macrophytes } & Paspalum distichum & gdw & 109.5 & 0 & $28.3 \pm 27.2$ & 95.8 \\
\hline & Typha orientalis & $g d w$ & 306.4 & 0 & $16.0 \pm 64.9$ & 404.5 \\
\hline & Spirodela polyrhiza & $g d w$ & 7.8 & 0 & $2.0 \pm 2.0$ & 99.1 \\
\hline & Salvinia natans & $g d w$ & 7.1 & 0 & $0.4 \pm 1.3$ & 360.0 \\
\hline & Nelumbo nucifera & $g d w$ & 36.1 & 0 & $10.0 \pm 9.8$ & 98.9 \\
\hline & Trapa japonica & $g d w$ & 26.9 & 0 & $4.3 \pm 7.5$ & 175.3 \\
\hline & Hydrocharis dubia & $g d w$ & 4.7 & 0 & $0.5 \pm 1.0$ & 183.5 \\
\hline & Ceratophyllum demersum & gdw & 2.4 & 0 & $0.5 \pm 0.7$ & 135.4 \\
\hline & Hydrilla verticillata & $g d w$ & 0.8 & 0 & $0.1 \pm 0.2$ & 208.6 \\
\hline & Najas graminea & $g d w$ & 1.3 & 0 & $0.1 \pm 0.2$ & 307.2 \\
\hline
\end{tabular}

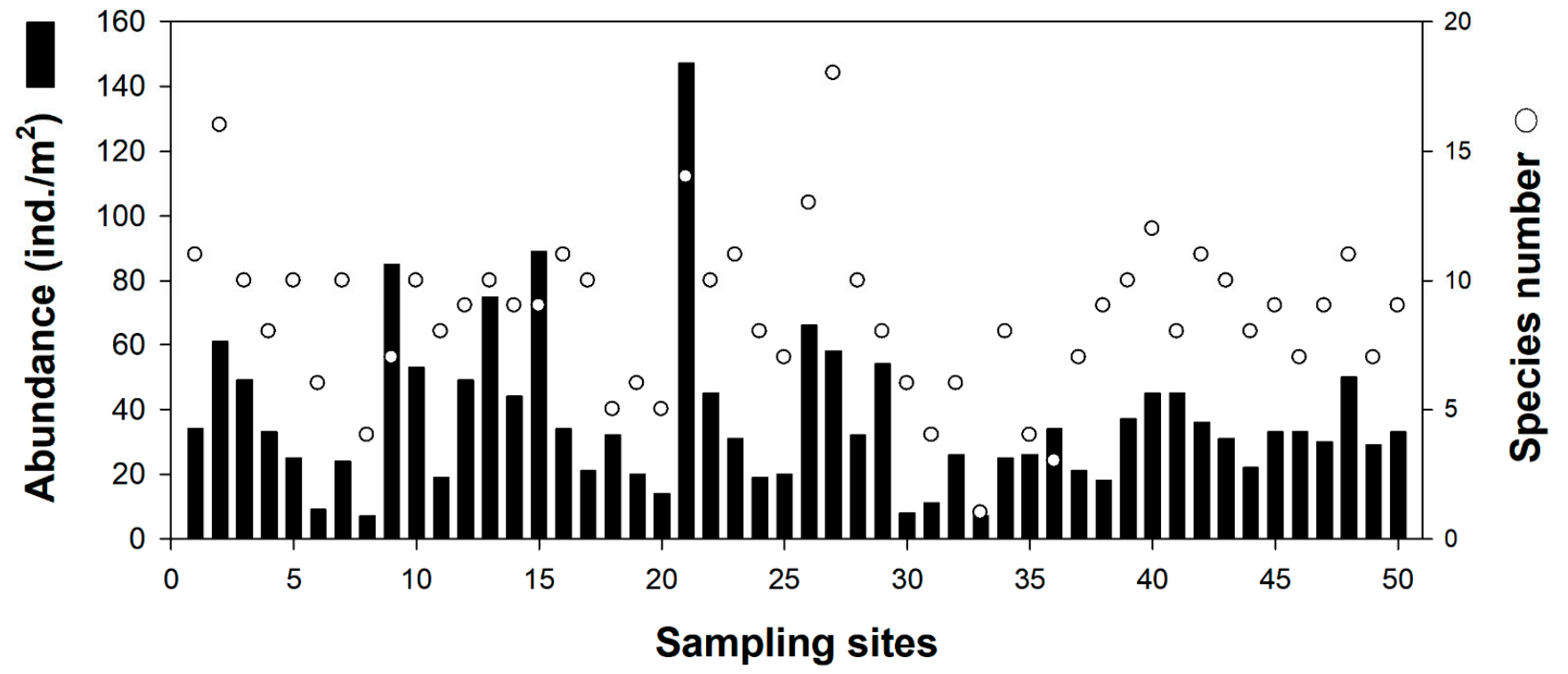

Figure 2. Abundance and species number of invertebrates from 50 sampling sites.

\subsection{Classification of Variable Features}

The SOM model was adaptively fitted to the input data (quantization error = 1.14; topographic error $=0.00)$, and the optimal structure of the SOM model consisted of 35 hexagonal nodes $(7 \times 5$ array; Figure 3$)$. The U-matrix (Figure $3 a)$ and the distance between nodes (Figure $3 b$ ) identified a total of three distinctive clusters. Clusters 1 and 2 could be divided into two sub-clusters (i.e., 1-1 and 1-2; 2-1, and 2-2). Subsequent clustering was conducted based on a darker area within two different parts. The hierarchical clustering method revealed the boundary of the nodes in clusters, as shown in Figure $3 \mathrm{~b}$. The characteristics of each input variable in every cluster are summarized in Table 2, which presents the mean values of each variable. 
(a)

a) U-matrix

(b)

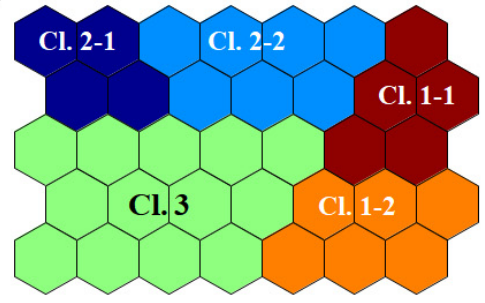

(c)

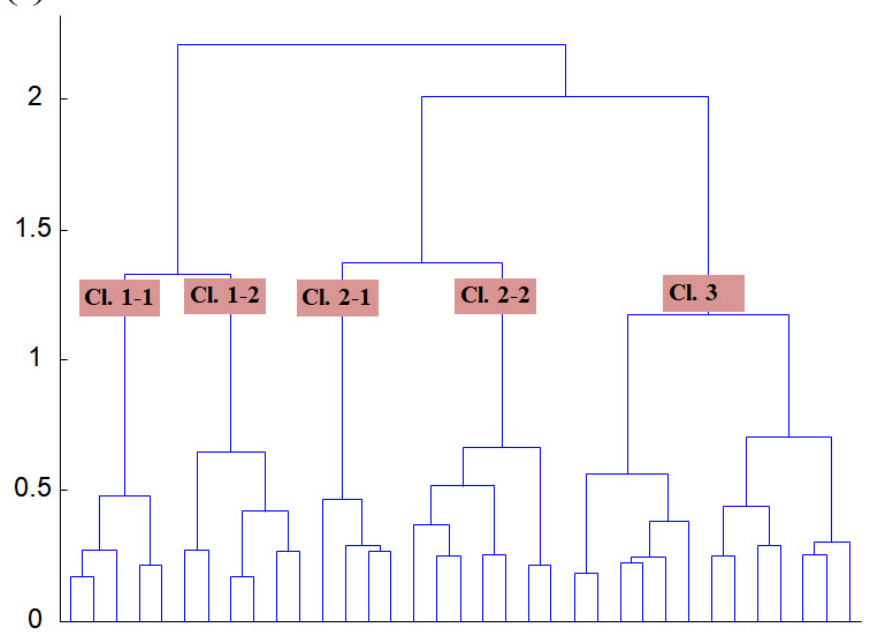

Figure 3. Clustering through data learning by the self-organizing map. (a) U-matrix, (b) clustering result, and (c) hierarchical dendrogram. $\mathrm{Cl}$., cluster. The darker the color of U-matrix (i.e., dark gray to black), the higher the difference between nodes (hexagons).

Table 2. Data configuration for the self-organizing map and averages of input variables for each of the clusters. Significant differences between clusters were based on one-way ANOVA $(\mathrm{df}=4)$.

\begin{tabular}{|c|c|c|c|c|c|c|c|c|}
\hline \multirow{2}{*}{ Factors } & \multirow{2}{*}{ Variables } & \multicolumn{5}{|c|}{ Clusters } & \multicolumn{2}{|c|}{ Significance } \\
\hline & & $1-1$ & $1-2$ & $2-1$ & $2-2$ & 3 & F & $p$ \\
\hline \multirow{5}{*}{$\begin{array}{l}\text { Environmental } \\
\text { variables }\end{array}$} & Water depth & 48.2 & 35.6 & 56.2 & 48.9 & 45.9 & 3.315 & $<0.05$ \\
\hline & $\mathrm{pH}$ & 7.2 & 7.2 & 7.2 & 7.2 & 7.2 & 0.407 & 0.803 \\
\hline & Conductivity & 218.4 & 216.7 & 219.7 & 215.5 & 216.8 & 0.468 & 0.759 \\
\hline & Turbidity & 21.0 & 20.2 & 23.3 & 23.2 & 19.7 & 2.694 & $<0.05$ \\
\hline & Chlorophyll a & 12.7 & 11.3 & 15.3 & 15.5 & 11.9 & 2.646 & $<0.05$ \\
\hline \multirow{10}{*}{ Macrophytes } & Paspalum distichum & 17.8 & 63.5 & 10.3 & 3.9 & 33.4 & 2.921 & $<0.05$ \\
\hline & Typha orientalis & 0 & 89.1 & 0 & 0 & 0 & 4.462 & $<0.01$ \\
\hline & Spirodela polyrhiza & 1.3 & 2.0 & 0.5 & 3.6 & 1.9 & 2.993 & $<0.05$ \\
\hline & Salvinia natans & 0.8 & 1.0 & 0 & 0 & 0.1 & 1.717 & 0.163 \\
\hline & Nelumbo nucifera & 4.6 & 5.4 & 12.1 & 6.4 & 16.1 & 0.768 & 0.551 \\
\hline & Trapa japonica & 0.6 & 0 & 8.6 & 15.0 & 1.7 & 2.691 & $<0.05$ \\
\hline & Hydrocharis dubia & 0 & 0 & 0.6 & 1.7 & 0.4 & 8.734 & $<0.001$ \\
\hline & Ceratophyllum demersum & 0.2 & 0 & 1.6 & 0.3 & 0.7 & 8.421 & $<0.001$ \\
\hline & Hydrilla verticillata & 0 & 0 & 0.4 & 0 & 0.1 & 7.227 & $<0.001$ \\
\hline & Najas graminea & 0 & 0 & 0.3 & 0.1 & 0.1 & 1.663 & 0.175 \\
\hline \multirow{13}{*}{ Invertebrates } & Viviparidae & 0.4 & 1.9 & 0.4 & 0.7 & 2.6 & 5.947 & $<0.01$ \\
\hline & Bithyniidae & 0.2 & 0 & 7.0 & 11.8 & 1.8 & 14.534 & $<0.001$ \\
\hline & Lymnaeidae & 2.7 & 5.1 & 9.4 & 5.2 & 14.3 & 2.691 & $<0.05$ \\
\hline & Physidae & 3.7 & 3.2 & 11.2 & 4.0 & 8.8 & 2.921 & $<0.05$ \\
\hline & Planorbidae & 3.3 & 35.3 & 1.6 & 0.7 & 7.6 & 5.456 & $<0.01$ \\
\hline & Coenagrionidae & 0.4 & 0.4 & 1.0 & 1.2 & 0.9 & 0.768 & 0.551 \\
\hline & Corduliidae & 0.0 & 0.7 & 0.4 & 0.1 & 0.2 & 1.717 & 0.163 \\
\hline & Libellulidae & 0.9 & 1.1 & 4.2 & 0.3 & 1.8 & 3.101 & 0.025 \\
\hline & Belostomatidae & 1.9 & 2.2 & 2.6 & 2.0 & 4.1 & 2.512 & 0.055 \\
\hline & Hydrophilidae & 0.1 & 1.2 & 0.6 & 0.1 & 0.8 & 3.389 & $<0.05$ \\
\hline & Stratiomyidae & 0 & 0 & 0.8 & 0 & 0.3 & 2.691 & $<0.05$ \\
\hline & Ecnomidae & 0 & 0 & 0 & 0 & 0.6 & 2.432 & 0.061 \\
\hline & Pyralidae & 0 & 0.3 & 0.2 & 0.1 & 0.6 & 0.683 & 0.061 \\
\hline
\end{tabular}

By visually comparing the component planes shown in Figure 4, each invertebrate group exhibited different shapes and gradients on the map plane. A large proportion of 
gastropods, such as Lymnaeidae, Physidae, and Viviparidae, were concentrated in cluster 3, along with other invertebrates (Belostomatidae, Ecnomidae, and Pyralidae). Bithyniidae and Coenagrionidae were distributed in cluster 2-2, and Planorbidae and Corduliidae were concentrated in cluster 1-2. Hydrophilidae was widely distributed in the lower part of the map. The remaining invertebrate group (i.e., Libellulidae) was dispersed on the map plane.

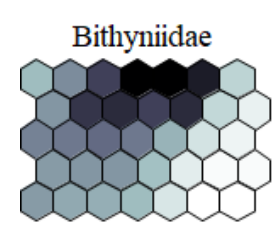

Belostomatidae

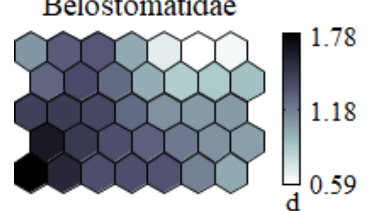

$\square_{\mathrm{d}} 0.59$
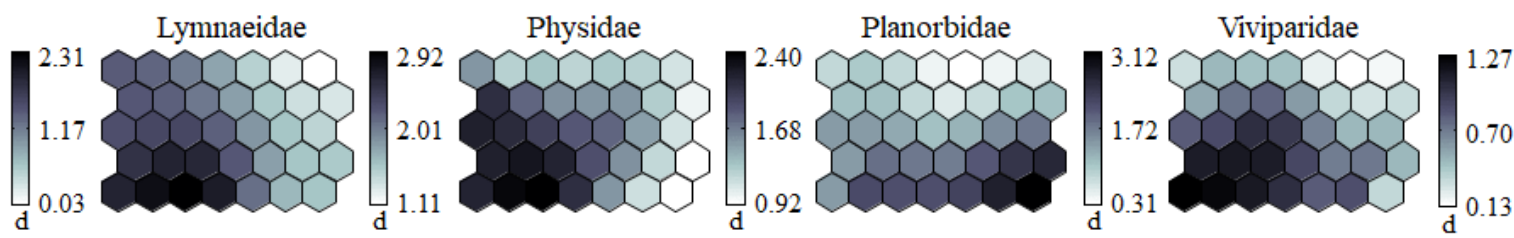

Corduliidae Coenagrionidae
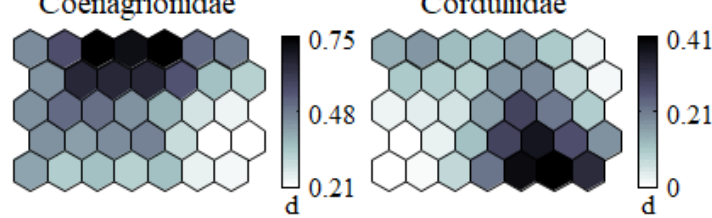

Ecnomidae

Hydrophilidae
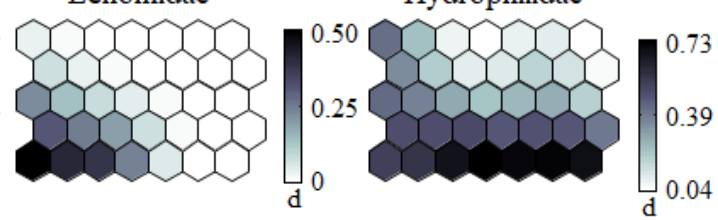

Libellulidae

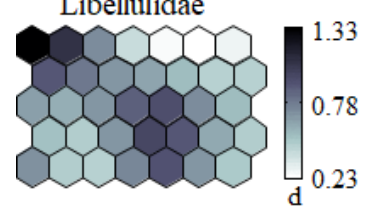

Pyralidae

Stratiomyidae
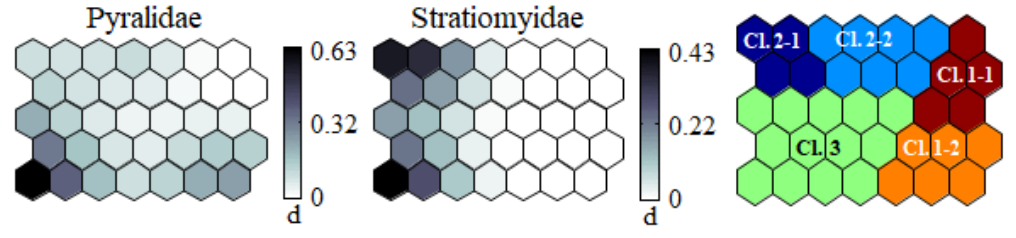

Figure 4. Component map of 24 invertebrate groups. Each band shows the abundance of each invertebrate, transformed by a natural logarithm.

In addition to the 13 invertebrate groups, five environmental variables and eight macrophyte species were displayed on the SOM (Figure 5). Each variable exhibited a different gradient on the planes, and these gradients were helpful for interpreting the influence of environmental variables and macrophytes on the distribution of invertebrate communities. Depth and turbidity were mainly concentrated in clusters $2-1$ and 2-2, whereas the remaining environmental variables were irregularly distributed. In contrast to the environmental variables, the biomass of aquatic macrophytes was clearly separated on the map plane. When we masked the biomass data of each macrophyte species over the trained SOM plane, a distinguishable distribution pattern of plant species was observed. $P$. distichum, T. orientalis, S. natans, and N. nucifera were located in the lower part of the map. T. orientalis and S. natans were distributed in the right lower corner of the map (cluster 1-2), while the sampling sites where N. nucifera was abundant were concentrated in the left lower corner of the map (cluster 3). In contrast, macrophyte species, such as S. polyrhiza, T. japonica, H. dubia, C. demersum, H. verticillata, and $N$. graminea, belonged to the upper parts of the map. S. polyrhiza, T. japonica, and H. dubia were distributed in the middle of the map (cluster 2-2), while C. demersum, $H$. verticillata, and $N$. graminea were in the left upper corner of the map (cluster 2-1). Cluster 1-1 was supported by an open water surface with few aquatic macrophytes.

Most invertebrate groups were associated with aquatic macrophyte species. The sampling sites where P. distichum and N. nucifera were abundant (i.e., higher biomass) supported a high density of Lymnaeidae, Physidae, Viviparidae, Belostomatidae, Ecnomidae, and Pyralidae (Figure 4). The spatial distribution of Bithyniidae and Coenagrionidae was clearly associated with the high biomass of free-floating and floating-leaved macrophyte species, such as S. polyrhiza, T. japonica, and H. dubia. Planorbidae and Corduliidae were abundant at sites with high biomass of T. orientalis and S. natans, whereas Hydrophilidae was distributed at sampling sites where P. distichum was abundant. In contrast, submerged macrophyte species (i.e., C. demersum, H. verticillata, and N. graminea) seemed to have little effect on the spatial distribution of most invertebrates. Sampling sites where submerged 
macrophyte species were abundant supported only moderate densities of Lymnaeidae,

Physidae, Belostomatidae, Coenagrionidae, and Libellulidae.

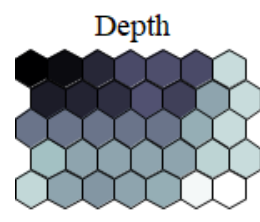

P. distichum

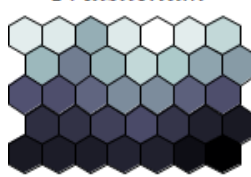

T.japonica
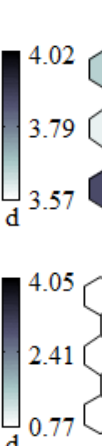

T. orientalis

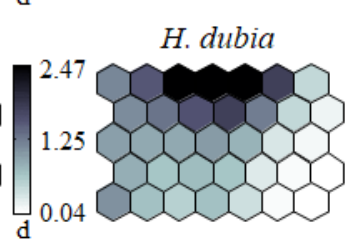

$\mathrm{pH}$

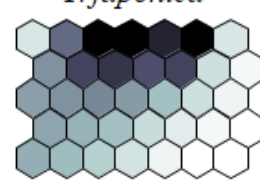

$\mathrm{d} 0.04$
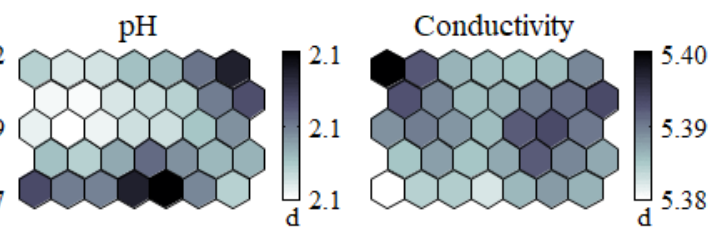

Turbidity

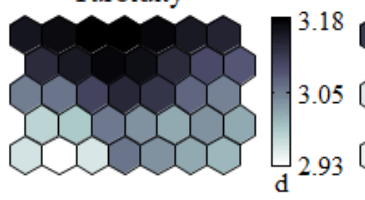

S. natans

S. polyrhiza
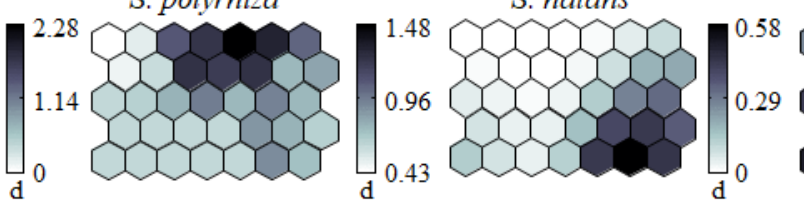

C. demersum
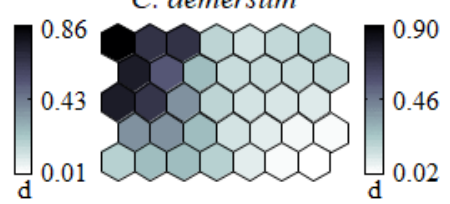

Chlorophyll a

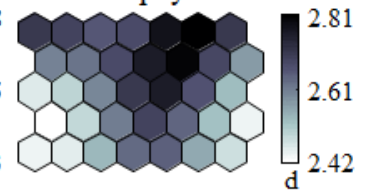

N. nucifera

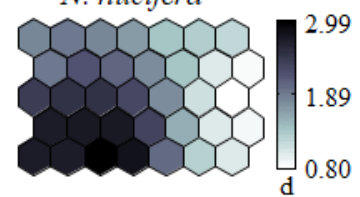

N. graminea

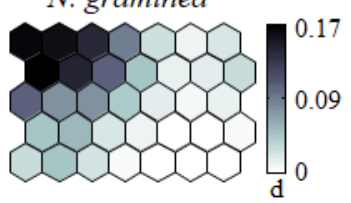

Figure 5. Segmentation of the data between environmental variables and biomass per macrophyte species. The distribution is partitioned according to macrophyte species. Cluster orientation is the same as in Figure 4.

\subsection{Distribution of Gastropod Communities on Macrophyte Species}

The distribution of the seven gastropod species clearly differed among the 10 plant species (Figure 6; one-way ANOVA, $p<0.05$ ). The different preferences for each plant species by gastropods were similar to the distribution characteristics of the gastropods within the 50 quadrats (see Figures 4 and 5). P. distichum and N. nucifera supported a high density of four gastropod species (Hippeutis cantori (cowworm), Parafossarulus manchouricus, Polypylis hemisphaerula, and R. auricularia). Cipangopaludina chinensis malleata was abundant on the surface of T. japonica and H. dubia, whereas the density of Physa acuta was higher on the surface of T. orientalis. In contrast, free-floating (S. polyrhiza and S. natans) and submerged (C. demersum, $H$. verticillata, and N. graminea) plant species were rarely selected by gastropods.

The species composition of epiphytic algae among plant species was slightly different, but the total abundance was significantly different (one-way ANOVA, $p<0.05$; Table 3 ). Bacillariophyceae were the most abundant on the surface of all plant species, followed by Chlorophyceae and Cyanophyceae. The highest abundance of epiphytic algae was found on the surface of submerged macrophyte species (C. demersum, $H$. verticillata, and $N$. graminea), while emergent macrophytes ( $P$. distichum and $T$. orientalis) supported a low abundance of epiphytic algae. The algal abundance on the surface of N. nucifera was similar to that of submerged macrophytes (706 and 945 cells $/ \mathrm{gdw}^{-1}$ in spring and autumn, respectively). 


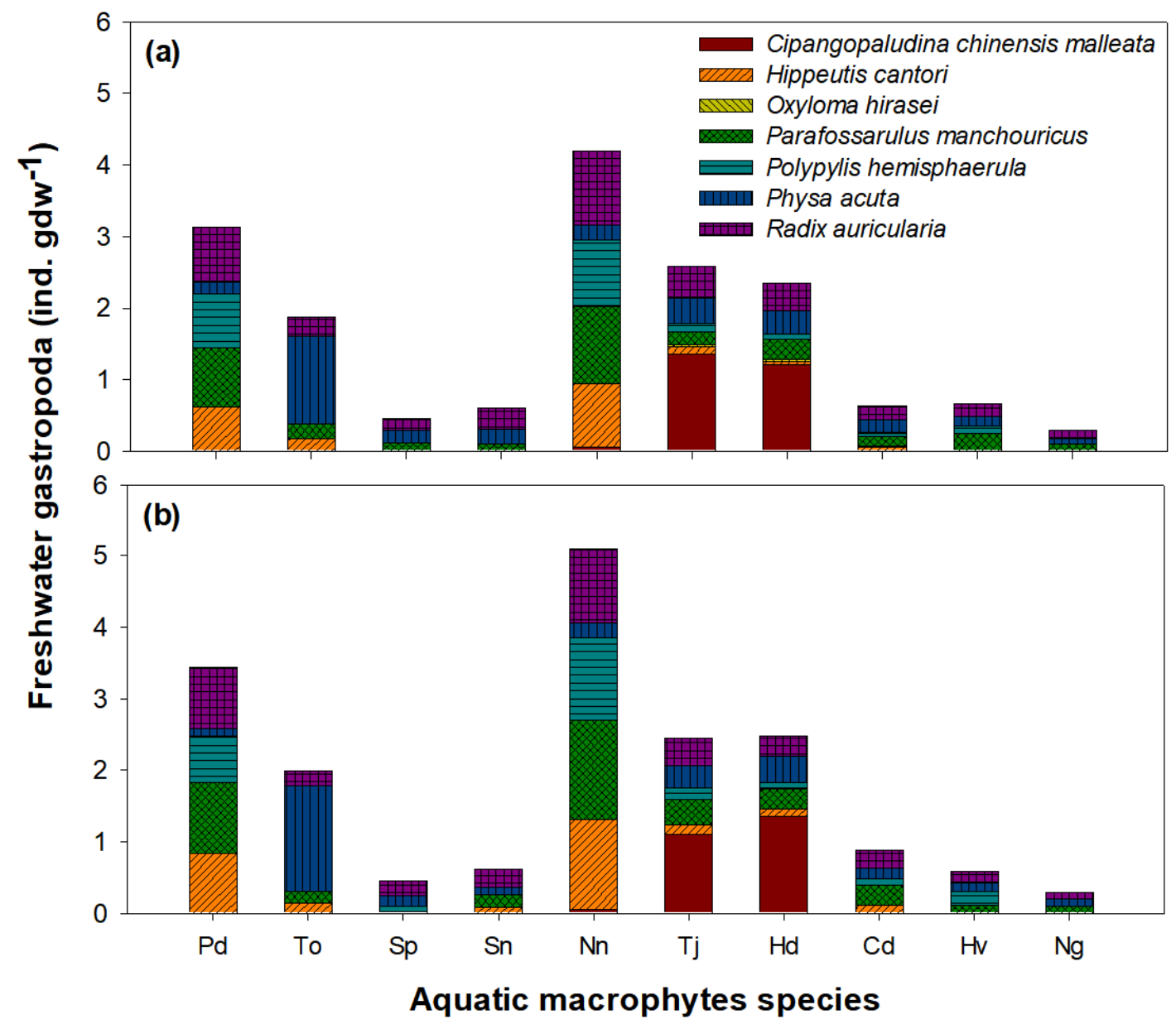

Figure 6. Abundance and species number of gastropods among macrophyte species. (a) Spring and (b) autumn. Pd, Paspalum distichum; To, Typha orientalis; Sp, Spirodela polyrhiza; Sn, Salvinia natans; Nn, Nelumbo nucifera; Tj, Trapa japonica; Hd, Hydrocharis dubia; Cd, Ceratophyllum demersum; $\mathrm{Hv}$, Hydrilla verticillata; $\mathrm{Ng}$, Najas graminea.

Table 3. Seasonal mean abundance of major epiphytic algal groups collected from each macrophyte species (cells/gdw ${ }^{-1}$ ) at the study area. Pd, Paspalum distichum; To, Typha orientalis; Sp, Spirodela polyrhiza; Sn, Salvinia natans; Nn, Nelumbo nucifera; $\mathrm{Tj}$, Trapa japonica; Hd, Hydrocharis dubia; Cd, Ceratophyllum demersum; Hv, Hydrilla verticillata; Ng, Najas graminea.

\begin{tabular}{cccccccccccc}
\hline Season & Algal Groups & $\mathbf{P d}$ & $\mathbf{T o}$ & $\mathbf{S p}$ & $\mathbf{S n}$ & $\mathbf{N n}$ & $\mathbf{T j}$ & $\mathbf{H d}$ & $\mathbf{C d}$ & $\mathbf{H v}$ & $\mathbf{N g}$ \\
\hline \multirow{6}{*}{ Spring } & Chlorophyceae & 41 & 42 & 94 & 112 & 138 & 68 & 89 & 168 & 174 \\
& Bacillariophyceae & 87 & 93 & 168 & 189 & 237 & 128 & 116 & 315 & 358 & 345 \\
& Cyanophyceae & 43 & 40 & 62 & 84 & 82 & 30 & 75 & 89 & 92 & 94 \\
& Euglenophyceae & 31 & 27 & 34 & 38 & 51 & 21 & 46 & 68 & 61 & 72 \\
& Chrysophyceae & 16 & 15 & 38 & 42 & 47 & 23 & 56 & 52 & 55 \\
& Synurophyceae & 11 & 15 & 63 & 68 & 62 & 27 & 38 & 31 & 29 & 48 \\
& Dinophyceae & 13 & 13 & 81 & 78 & 89 & 18 & 35 & 36 & 32 & 37 \\
& Total & 242 & 245 & 540 & 611 & 706 & 315 & 455 & 759 & 801 & 795 \\
\hline \multirow{5}{*}{ Autumn } & Chlorophyceae & 56 & 62 & 128 & 168 & 224 & 80 & 93 & 214 & 238 & 246 \\
& Bacillariophyceae & 97 & 134 & 238 & 259 & 374 & 146 & 138 & 538 & 505 & 186 \\
& Cyanophyceae & 51 & 57 & 119 & 98 & 118 & 84 & 92 & 135 & 146 & 124 \\
& Euglenophyceae & 31 & 32 & 63 & 54 & 89 & 84 & 79 & 141 & 175 & 132 \\
& Chrysophyceae & 23 & 29 & 31 & 35 & 46 & 48 & 70 & 96 & 110 & 74 \\
& Synurophyceae & 16 & 20 & 46 & 50 & 52 & 46 & 48 & 78 & 52 & 38 \\
& Dinophyceae & 15 & 25 & 34 & 48 & 42 & 20 & 35 & 41 & 35 & 28 \\
& Total & 289 & 359 & 659 & 712 & 945 & 508 & 555 & 1243 & 1261 & 828 \\
\hline
\end{tabular}




\section{Discussion}

\subsection{Characterization of Clusters}

The SOM model clustered the field data into five main clusters, thus suggesting distinct relationships between aquatic macrophytes and invertebrate groups. We observed clear zonation in the species composition and biomass of aquatic macrophyte, resulting in different spatial distributions of invertebrate groups. These results showed that the microhabitat structure provided by aquatic macrophytes governed invertebrate communities in the wetland.

The characteristics of the clusters were as follows:

- Cluster 1-1 included sampling sites with high $\mathrm{pH}$ and turbidity and low abundance of aquatic macrophytes and invertebrates.

- Cluster 1-2 showed a high biomass of T. orientalis and S. polyrhiza, and the highest abundance of Planorbidae, Corduliidae, and Hydrophilidae. However, water depth and chlorophyll-a concentration were lower in this cluster.

- Cluster 2-1 was characterized by greater water depth, conductivity, turbidity, and chlorophyll-a concentration, as well as a high biomass of submerged macrophyte species (C. demersum, $H$. verticillata, and $N$. graminea). Although this cluster supported a high abundance of Lymnaeidae, Physidae, Belostomatidae, Coenagrionidae, and Libellulidae, these invertebrates were not as abundant as they were in clusters 2-2 and 3.

- Cluster 2-2 included sampling sites where S. polyrhiza, T. japonica, and H. dubia were abundant, along with high numbers of Bithyniidae and Coenagrionidae. Sampling sites with high turbidity and chlorophyll-a concentration were also observed in this cluster.

- Cluster 3 contained sites with high biomass of T. orientalis and S. natans. Invertebrate groups, such as Lymnaeidae, Physidae, Viviparidae, Belostomatidae, Ecnomidae, and Hydrophilidae, were present in high abundance.

The above summary suggests that different macrophyte species affected the abundance and distribution of invertebrates. In particular, gastropod abundance was positively or correlated to emergent (P. distichum and T. orientalis) and floating-leaved (N. nucifera, T. japonica, and H. dubia) macrophyte species.

Although some empirical studies have suggested a clear relationship between environmental variables and invertebrate communities [53,54], in the present study we did not find such relationships. These factors were evenly distributed on the trained SOM plane, which may indicate that the measured parameters did not have a relationship with the well-clustered invertebrate patterns. The 50 quadrats were located in similar areas, which can lead to only small environmental differences. However, the seasonality of environmental variables can affect the temporal distribution of invertebrates. Consequently, we considered that the local habitat heterogeneity of shallow wetlands was directly governed by aquatic macrophytes, and we used these to determine the spatial distribution of invertebrate groups.

\subsection{Effect of Microhabitats on Invertebrate Distribution}

Microhabitats constructed by macrophytes are arrangements of physical structures that determine the distribution of aquatic organisms in freshwater ecosystems [55]. In general, plant zonation depends on the depth of the bottom substrate in the water [56] and strongly affects the distribution of many aquatic organisms and the interactions among biological communities $[57,58]$. In the present study, we found that the spatial distribution of invertebrates collected from 50 quadrats substantially varied and was clearly influenced by the different aquatic macrophytes. In particular, the areas covered by P. distichum and N. nucifera supported the most diverse groups of invertebrates (Lymnaeidae, Physidae, Viviparidae, Belostomatidae, Ecnomidae, and Hydrophilidae). These macrophyte species have relatively large substrate surfaces as well as relatively hard stems and leaves, making them suitable habitats to support high abundances of invertebrates. Bithyniidae and 
Coenagrionidae were clearly linked to S. polyrhiza, T. japonica, and H. dubia, whereas Planorbidae, Corduliidae, and Hydrophilidae were abundant on the surface of T. orientalis and S. natans. Although S. polyrhiza and S. natans positively influenced the abundance of some invertebrate groups, we assumed that free-floating macrophyte species were less preferred by invertebrates. For example, since S. polyrhiza and S. natans float on the water surface, there is a possibility of them sinking if many invertebrates were attached to the plant. These free-floating macrophytes are abundant in spaces with a high cover of other plant species (e.g., emergent and floating-leaved macrophytes) because they can grow well in narrow spaces. Thus, S. polyrhiza had a similar pattern to those of T. japonica and H. dubia, and S. natans was clearly related to T. orientalis in the SOM map. The freefloating macrophytes were not preferred by invertebrates but appeared to be supported by a high abundance of invertebrates because they had a similar spatial distribution as plants where invertebrates were abundant. This distribution pattern was also observed in submerged macrophytes. Although submerged macrophytes grow entirely underwater, except for their roots, they tend to have soft stems and leaves and form poor habitats for many invertebrates.

Different distribution patterns for each macrophyte were also reflected in the distribution of gastropods. Seven gastropod species were found, mainly on the surface of emergent (P. distichum and T. orientalis) and floating-leaved (N. nucifera, T. japonica, and $H$. dubia) plants, while free-floating and submerged macrophytes supported a relatively low abundance of gastropods. We speculate that the different distribution of gastropods is attributable to their area as well as the material of leaves and stems of the plant species. However, the distribution of gastropods was less strongly related to the abundance of algae attached to each plant species. A high abundance of epiphytic algae was found on the surface of submerged macrophyte species, such as $C$. demersum and $H$. verticillata; however, most gastropods did not select submerged macrophytes for their habitat. Furthermore, although algal abundance was relatively low on the surface of emergent macrophytes (P. distichum and T. orientalis), a number of gastropod species was observed on the stem surface of emergent macrophytes. We found that the abundance of epiphytic algae per plant area did not significantly affect the distribution of gastropods, which can be explained by the fact that gastropods can move through a relatively large range of habitats.

The preference for certain aquatic macrophytes by invertebrates differs from the results of previous studies. Choi et al. [2] and Fukui et al. [59] suggested that emergent or free-floating macrophytes were not suitable habitats to support diverse animals not only because part of the plant was submerged in the water but also because the leaves and stems were relatively simple structures. Areas where emergent or free-floating macrophytes were abundant were less complex and heterogeneous. Choi et al. [11] also found that these plants supported relatively low numbers of epiphytic microinvertebrates. In contrast, the presence of submerged plants increases the structural complexity of habitats because they occupy a large area in the water as well as providing heterogeneous leaves and stems. Therefore, submerged plants are presumably more efficient habitats for various animals. However, we found that the functionality and habitat efficiency provided by different morphological characteristics of macrophytes did not offer a clear advantage for relatively large invertebrates. Relatively small-sized rotifers and cladocerans utilize food-rich or predator-avoidable spaces as their optimal habitat, but invertebrates seek habitat that physically supports their bodies. The leaves and stems of P. distichum and N. nucifera are relatively wide and hard, and they are more widely distributed than other plants, making them suitable for various invertebrates. Although these plant species support a low abundance of epiphytic algae per unit area, they have a large surface area, so they are useful as habitats for scrapers such as gastropods [60]. The low abundance of algae on each plant species may result from gastropod overgrazing. In addition, P. distichum and $N$. nucifera can be used as sturdy substrates for odonatan larvae to leave the water when they grow into the adult stage [61]. De Marco Jr et al. [62] and Remsburg and Turner [63] also suggested that emergent macrophytes influence the oviposition and territorial behavior 
of Libellulidae, a common odonatan family. In addition, physical structures caused by macrophytes located above the surface of the water are important for adult odonatans when they search for food or mates [64].

\subsection{Management Strategy for Freshwater Ecosystems for Invertebrate Diversity}

In the present study, we found that wetlands and shallow reservoirs located in South Korea were suitable for supporting various invertebrate species. In these freshwater ecosystems, low water velocity and shallow water depth not only provided a suitable environment for invertebrate population growth but also promoted the growth of plant species such as P. distichum, T. orientalis, and N. nucifera. These three macrophyte species are densely distributed in the littoral area, with stems and leaves growing high above the water creating shade, which can inhibit the occurrence of other plants [65]. Furthermore, the inflow of various nutrients (e.g., nitrogen and phosphorus) from the surrounding agricultural and residential areas continue to affect wetlands and reservoirs [66], resulting in the excessive spread and dominance of some plant species. Choi and Kim [12] suggested that the autumn growth of submerged plants was clearly disturbed by free-floating and floating-leaved macrophytes that covered the water surface widely in summer. An excessive level of cover from free-floating and floating-leaved macrophytes on the water surface blocks the flow of light into the water, which can negatively affect the growth and distribution of submerged plants. Although we observed 10 plant species in Jangcheok Reservoir, in most wetlands and shallow reservoirs located in South Korea, aquatic macrophytes are dominated by a few plant species, such as $P$. distichum, T. orientalis, and N. nucifera, rather than a high diversity of plant species coexisting through seasonal succession and interactions [2]. The dominance of these plant species positively affected the distribution and species diversity of some invertebrates.

The frequent distribution of P. distichum, T. orientalis, and N. nucifera in South Korean wetlands and reservoirs coincides with South Korea's recent restoration of wetland plants. The leaves and stems of these plant species occupy more space above the water surface than under the water, and because of their quick growth, they can significantly increase the landscape or esthetic factors of wetlands and reservoirs. Therefore, these three species are usually planted when wetlands or reservoirs are restored or newly constructed. However, this limited plant selection can lead to an imbalance in terms of biodiversity, including invertebrates. Although emergent macrophytes are preferred habitats for invertebrates, microinvertebrates such as rotifers and cladocerans are rarely found in spaces that have a high cover of emergent macrophyte species $[11,16]$. The low diversity of rotifers and cladocerans can negatively affect some invertebrates that use them as food sources. In addition, rotifers and cladocerans, which mainly consume phytoplankton, strongly affect the trophic status of wetlands or reservoirs, which in turn can affect the habitat quality of invertebrates. In particular, the high consumption of phytoplankton by cladocerans has a significant effect on improving the water quality of wetlands and reservoirs [67]. In this respect, habitat restoration to induce the distribution or growth of emergent macrophytes may be inefficient. Water covered by a wide variety of plant species is necessary to maintain the health of freshwater food webs and to secure species diversity in various biological communities, including invertebrates. Therefore, wetland restoration plans that focus on species with high visibility and emphasize only existing esthetic aspects (e.g., emerging plant species) need to be revised.

Most of the wetlands and shallow reservoirs located in South Korea are small areas, and the lack of connectivity between them suggests that invertebrate species diversity depends on local habitat characteristics. Consequently, the species diversity of invertebrates is determined by the local population growth of each community since the immigration or emigration of communities or individuals is restricted compared to more connected aquatic ecosystems. In conclusion, to maintain high invertebrate species diversity in wetlands and reservoirs in South Korea, conservation and management measures are needed to 
secure highly heterogeneous spaces by encouraging the local distribution of a variety of plant species.

Author Contributions: Conceptualization, S.-H.S., D.K. and J.-Y.C.; methodology, S.-K.K.; validation, S.-K.K. and J.-Y.C.; formal analysis, J.-Y.C.; investigation, S.-J.K. and J.-H.I.; resources, D.K., and J.-Y.C.; data curation, J.-Y.C.; writing—original draft preparation, D.K. and J.-Y.C.; writing—review and editing, D.K. and J.-Y.C.; visualization, J.-Y.C.; supervision, J.-Y.C.; project administration, D.K. and J.-Y.C.; funding acquisition, S.-J.K. and S.-K.K. All authors have read and agreed to the published version of the manuscript.

Funding: This research was supported by the Fundamental Research funded by the National Institute of Ecology (NIE-2015-04).

Institutional Review Board Statement: Not applicable.

Informed Consent Statement: Not applicable.

Data Availability Statement: The data presented in this study are available on request from the corresponding author. The data are not publicly available due to restrictions on the right of privacy.

Conflicts of Interest: The authors declare no conflict of interest.

\section{References}

1. Heino, J.; Virkkala, R.; Toivonen, H. Climate change and freshwater biodiversity: Detected patterns, future trends and adaptations in northern regions. Biol. Rev. 2009, 84, 39-54. [CrossRef] [PubMed]

2. Choi, J.Y.; Jeong, K.S.; Kim, S.K.; La, G.H.; Chang, K.H.; Joo, G.J. Role of macrophytes as microhabitats for zooplankton community in lentic freshwater ecosystems of South Korea. Ecol. Inform. 2014, 24, 177-185. [CrossRef]

3. Polo-Cavia, N.; López, P.; Martín, J. Interspecific differences in responses to predation risk may confer competitive advantages to invasive freshwater turtle species. Ethology 2008, 114, 115-123. [CrossRef]

4. Eero, M.; Vinther, M.; Haslob, H.; Huwer, B.; Casini, M.; Storr-Paulsen, M.; Köster, F.W. Spatial management of marine resources can enhance the recovery of predators and avoid local depletion of forage fish. Conserv. Lett. 2012, 5, 486-492. [CrossRef]

5. Arnan, X.; Gaucherel, C.; Andersen, A.N. Dominance and species co-occurrence in highly diverse ant communities: A test of the interstitial hypothesis and discovery of a three-tiered competition cascade. Oecologia 2011, 166, 783-794. [CrossRef]

6. Allen, D.C.; Vaughn, C.C. Complex hydraulic and substrate variables limit freshwater mussel species richness and abundance. J. North Am. Benthol. Soc. 2010, 29, 383-394. [CrossRef]

7. MacNeil, C.; Platvoet, D.; Dick, J.T. Potential roles for differential body size and microhabitat complexity in mediating biotic interactions within invasive freshwater amphipod assemblages. Fundam. Appl. Limnol. 2008, 172, 175. [CrossRef]

8. Svanbäck, R.; Eklöv, P. Effects of habitat and food resources on morphology and ontogenetic growth trajectories in perch. Oecologia 2002, 131, 61-70. [CrossRef]

9. Christie, H.; Norderhaug, K.M.; Fredriksen, S. Macrophytes as habitat for fauna. Mar. Ecol. Prog. Ser. 2009, 396, 221-233. [CrossRef]

10. Thomaz, S.M.; Cunha, E.R.D. The role of macrophytes in habitat structuring in aquatic ecosystems: Methods of measurement, causes and consequences on animal assemblages' composition and biodiversity. Acta Limnol. Bras. 2010, 22, 218-236. [CrossRef]

11. Choi, J.Y.; Jeong, K.S.; La, G.H.; Kim, S.K.; Joo, G.J. Sustainment of epiphytic microinvertebrate assemblage in relation with different aquatic plant microhabitats in freshwater wetlands (South Korea). J. Limnol. 2014, 73, 197-202. [CrossRef]

12. Choi, J.Y.; Kim, S.K. Responses of rotifer community to microhabitat changes caused by summer-concentrated rainfall in a shallow reservoir, South Korea. Diversity 2020, 12, 113. [CrossRef]

13. Jeppesen, E.; Søndergaard, M.; Søndergaard, M.; Christoffersen, K. (Eds.) The Structuring Role of Submerged Macrophytes in Lakes; Springer Science \& Business Media: Berlin/Heidelberg, Germany, 2012; Volume 131.

14. Hempel, M.; Blume, M.; Blindow, I.; Gross, E.M. Epiphytic bacterial community composition on two common submerged macrophytes in brackish water and freshwater. BMC Microbiol. 2008, 8, 58. [CrossRef] [PubMed]

15. Van Donk, E.; van de Bund, W.J. Impact of submerged macrophytes including charophytes on phyto-and zooplankton communities: Allelopathy versus other mechanisms. Aquat. Bot. 2002, 72, 261-274. [CrossRef]

16. Choi, J.Y.; Kim, S.K.; Jeong, K.S.; Joo, G.J. Distribution pattern of epiphytic microcrustaceans in relation to different macrophyte microhabitats in a shallow wetland (Upo wetlands, South Korea). Oceanol. Hydrobiol. Stud. 2015, 44, 151. [CrossRef]

17. Stahr, K.J.; Kaemingk, M.A. An evaluation of emergent macrophytes and use among groups of aquatic taxa. Lake Reserv. Manag. 2017, 33, 314-323. [CrossRef]

18. Cazzanelli, M.; Warming, T.P.; Christoffersen, K.S. Emergent and floating-leaved macrophytes as refuge for zooplankton in a eutrophic temperate lake without submerged vegetation. Hydrobiologia 2008, 605, 113-122. [CrossRef]

19. Choi, J.Y.; Jeong, K.S.; La, G.H.; Joo, G.J. Effect of removal of free-floating macrophytes on zooplankton habitat in shallow wetland. Knowl. Manag. Aquat. Ecosyst. 2014, 414, 11. [CrossRef] 
20. Burks, R.L.; Mulderij, G.; Gross, E.; Jones, I.; Jacobsen, L.; Jeppesen, E.; Van Donk, E. Center stage: The crucial role of macrophytes in regulating trophic interactions in shallow lake wetlands. In Wetlands: Functioning, Biodiversity Conservation, and Restoration; Bobbink, R., Beltman, B., Verhoeven, J.T.A., Whigham, D.F., Eds.; Springer: Berlin/Heidelberg, Germany, 2006 ; pp. 37-59.

21. Nicolle, A.; Hansson, L.A.; Brönmark, C. Habitat structure and juvenile fish ontogeny shape zooplankton spring dynamics. Hydrobiologia 2010, 652, 119-125. [CrossRef]

22. Kuczyńska-Kippen, N.; Joniak, T. Zooplankton diversity and macrophyte biometry in shallow water bodies of various trophic state. Hydrobiologia 2016, 774, 39-51. [CrossRef]

23. Pastuchová, Z.; Lehotský, M.; Grešková, A. Influence of morphohydraulic habitat structure on invertebrate communities (Ephemeroptera, Plecoptera and Trichoptera). Biologia 2008, 63, 720-729. [CrossRef]

24. Amaral, P.H.M.D.; Silveira, L.S.D.; Rosa, B.F.J.V.; Oliveira, V.C.D.; Alves, R.D.G. Influence of habitat and land use on the assemblages of Ephemeroptera, Plecoptera, and Trichoptera in neotropical streams. J. Insect Sci. 2015, 15, 60. [CrossRef]

25. Butler, R.G.; Demaynadier, P.G. The significance of littoral and shoreline habitat integrity to the conservation of lacustrine damselflies (Odonata). J. Insect Conserv. 2008, 12, 23-36. [CrossRef]

26. Choi, J.Y.; Kim, S.K.; Kim, J.C.; Kwon, S.J. Habitat preferences and trophic position of Brachydiplax chalybea flavovittata Ris, 1911 (Insecta: Odonata) larvae in Youngsan River wetlands of South Korea. Insects 2020, 11, 273. [CrossRef]

27. Vasileva, S.Y.; Georgiev, D.G.; Gecheva, G.M. On the communities of freshwater gastropods on aquatic macrophytes in some water basins of southern Bulgaria. Ecol. Balk. 2011, 3, 11-17.

28. Lusardi, R.A.; Jeffres, C.A.; Moyle, P.B. Stream macrophytes increase invertebrate production and fish habitat utilization in a California stream. River Res. Appl. 2018, 34, 1003-1012. [CrossRef]

29. Ohtaka, A.; Narita, T.; Kamiya, T.; Katakura, H.; Araki, Y.; Im, S.; Chhay, R.; Tsukawaki, S. Composition of aquatic invertebrates associated with macrophytes in Lake Tonle Sap, Cambodia. Limnology 2011, 12, 137-144. [CrossRef]

30. Declerck, S.A.; Bakker, E.S.; van Lith, B.; Kersbergen, A.; van Donk, E. Effects of nutrient additions and macrophyte composition on invertebrate community assembly and diversity in experimental ponds. Basic Appl. Ecol. 2011, 12, 466-475. [CrossRef]

31. De Neiff, A.P.; Carignan, R. Macroinvertebrates on Eichhornia crassipes roots in two lakes of the Paran River floodplain. Hydrobiologia 1997, 345, 185-196. [CrossRef]

32. Irma, D.; Sofyatuddin, K. Diversity of gastropods and bivalves in mangrove ecosystem rehabilitation areas in Aceh Besar and Banda Aceh districts, Indonesia. Aquac. Aqua. Conserv. Legis. 2012, 5, 55-59.

33. Wang, H.J.; Pan, B.Z.; Liang, X.M.; Wang, H.Z. Gastropods on submersed macrophytes in Yangtze lakes: Community characteristics and empirical modelling. Int. Rev. Hydrobiol. 2006, 91, 521-538. [CrossRef]

34. Strong, E.E.; Gargominy, O.; Ponder, W.F.; Bouchet, P. Global diversity of gastropods (Gastropoda; Mollusca) in freshwater. In Freshwater Animal Diversity Assessment; Springer: Dordrecht, The Netherlands, 2007; pp. 149-166.

35. Johnson, P.D.; Bogan, A.E.; Brown, K.M.; Burkhead, N.M.; Cordeiro, J.R.; Garner, J.T.; Hartfield, P.D.; Lepitzki, D.A.W.; Mackie, G.L.; Pip, E.; et al. Conservation status of freshwater gastropods of Canada and the United States. Fisheries 2013, 38, 247-282. [CrossRef]

36. Jeong, K.S.; Kim, D.K.; Joo, G.J. Delayed influence of dam storage and discharge on the determination of seasonal proliferations of Microcystis aeruginosa and Stephanodiscus hantzschii in a regulated river system of the lower Nakdong River (South Korea). Water Res. 2007, 41, 1269-1279. [CrossRef] [PubMed]

37. Choi, J.Y.; Jeong, K.S.; Joo, G.J. Rainfall as dominant driver of rotifer dynamics in shallow wetlands: Evidence from a long-term data record (Upo Wetlands, South Korea). Int. Rev. Hydrobiol. 2015, 100, 21-33. [CrossRef]

38. Wetzel, R.G.; Likens, G.E. Composition and biomass of phytoplankton. In Limnological Analyses; Springer: New York, NY, USA, 2000; pp. 147-174.

39. Yoon, I.B. Aquatic Insects of Korea; Jeonghaengsa: Seoul, Korea, 1995.

40. Kwon, S.J.; Jun, Y.C.; Park, J.H. Benthic Macroinvertebrates; Nature and Ecology: Seoul, Korea, 2013; p. 791.

41. Kawai, T.; Tanida, K. Aquatic Insects of Japan: Manual with Keys and Illustrations; Tokai University Press: Kanagawa, Japan, 2005.

42. Kohonen, T. Self-Organizing Maps; Springer: New York, NY, USA, 1997.

43. Kohonen, T. Self-organized formation of topologically correct feature maps. Biol. Cybern. 1982, 43, 59-69. [CrossRef]

44. Odum, H.T. Ecological and General Systems: An Introduction to Systems Ecology; University Press of Colorado: Boulder, CO, USA, 1983.

45. Chon, T.S.; Park, Y.S.; Moon, K.H.; Cha, E.Y. Patterning communities by using an artificial neural network. Ecol. Model. 1996, 90, 69-78. [CrossRef]

46. Fielding, A.H. (Ed.) An introduction to machine learning methods. In Machine Learning Methods for Ecological Applications; Springer: Boston, MA, USA, 1999; pp. 1-35.

47. Kim, S.K.; Kim, J.C.; Joo, G.J.; Choi, J.Y. Response of the rotifer community to human-induced changes in the trophic state of a reservoir. Oceanol. Hydrobiol. Stud. 2020, 49, 329-344. [CrossRef]

48. Kohonen, T. Essentials of the self-organizing map. Neural Netw. 2013, 37, 52-65. [CrossRef]

49. Park, Y.S.; Song, M.Y.; Park, Y.C.; Oh, K.H.; Cho, E.; Chon, T.S. Community patterns of benthic macroinvertebrates collected on the national scale in Korea. Ecol. Model. 2007, 203, 26-33. [CrossRef]

50. Vesanto, J.; Alhoniemi, E. Clustering of the self-organizing map. IEEE Trans. Neural Netw. 2000, 11, 586-600. [CrossRef]

51. Uriarte, A.; Martín, F.D. Topology preservation in SOM. Int. J. Appl. Math. Comput. Sci. 2005, 1, 19-22. 
52. Cèrèghino, R.; Park, Y.S. Review of the self-organizing map (SOM) approach in water resources: Commentary. Environ. Modell. Softw. 2009, 24, 945-947. [CrossRef]

53. Briers, R.A.; Biggs, J. Spatial patterns in pond invertebrate communities: Separating environmental and distance effects. Aquat. Conserv. Mar. Freshw. Ecosyst. 2005, 15, 549-557. [CrossRef]

54. Hanson, M.A.; Bowe, S.E.; Ossman, F.G.; Fieberg, J.; Butler, M.G.; Koch, R. Influences of forest harvest and environmental gradients on aquatic invertebrate communities of seasonal ponds. Wetlands 2009, 29, 884-895. [CrossRef]

55. Chambers, P.A.; Lacoul, P.; Murphy, K.J.; Thomaz, S.M. Global diversity of aquatic macrophytes in freshwater. In Freshwater Animal Diversity Assessment; Balian, E.V., Lévêque, C., Segers, H., Martens, K., Eds.; Springer: Dordrecht, The Netherlands, 2007; pp. 9-26.

56. Xiao, K.; Yu, D.; Wu, Z. Differential effects of water depth and sediment type on clonal growth of the submersed macrophyte Vallisneria natans. Hydrobiologia 2007, 589, 265-272. [CrossRef]

57. Reitsema, R.E.; Meire, P.; Schoelynck, J. The future of freshwater macrophytes in a changing world: Dissolved organic carbon quantity and quality and its interactions with macrophytes. Front. Plant Sci. 2018, 9, 629. [CrossRef]

58. Dos Santos, N.G.; Stephan, L.R.; Otero, A.; Iglesias, C.; Castilho-Noll, M.S.M. How free-floating macrophytes influence interactions between planktivorous fish and zooplankton in tropical environments? An in-lake mesocosm approach. Hydrobiologia 2020, 847, 1357-1370. [CrossRef]

59. Fukui, D.A.I.; Murakami, M.; Nakano, S.; Aoi, T. Effect of emergent aquatic insects on bat foraging in a riparian forest. J. Anim. Ecol. 2006, 75, 1252-1258. [CrossRef]

60. Xie, Z.; Tang, T.; Ma, K.; Liu, R.; Qu, X.; Chen, J.; Cai, Q. Influence of environmental variables on macroinvertebrates in a macrophyte-dominated Chinese lake, with emphasis on the relationships between macrophyte heterogeneity and macroinvertebrate patterns. J. Freshw. Ecol. 2005, 20, 503-512. [CrossRef]

61. Brito, J.S.; Michelan, T.S.; Juen, L. Aquatic macrophytes are important substrates for Libellulidae (Odonata) larvae and adults. Limnology 2021, 22, 139-149. [CrossRef]

62. De Marco, J.P.; Latini, A.O.; Resende, D.C. Thermoregulatory constraints on behavior: Patterns in a Neotropical dragonfly assemblage. Neotrop. Entomol. 2005, 34, 155-162. [CrossRef]

63. Remsburg, A.J.; Turner, M.G. Aquatic and terrestrial drivers of dragonfly (Odonata) assemblages within and among northtemperate lakes. J. N. Am. Benthol. Soc. 2009, 28, 44-56. [CrossRef]

64. Iwai, N.; Akasaka, M.; Kadoya, T.; Ishida, S.; Aoki, T.; Higuchi, S.; Takamura, N. Examination of the link between life stages uncovered the mechanisms by which habitat characteristics affect odonates. Ecosphere 2017, 8, e01930. [CrossRef]

65. Short, F.T.; Kosten, S.; Morgan, P.A.; Malone, S.; Moore, G.E. Impacts of climate change on submerged and emergent wetland plants. Aquat. Bot. 2016, 135, 3-17. [CrossRef]

66. Peterjohn, W.T.; Correll, D.L. Nutrient dynamics in an agricultural watershed: Observations on the role of a riparian forest. Ecology 1984, 65, 1466-1475. [CrossRef]

67. Talling, J.F. Phytoplankton-zooplankton seasonal timing and the 'clear-water phase' in some English lakes. Freshw. Biol. 2003, 48, 39-52. [CrossRef] 